\title{
Alimentação e transformações urbanas em São Paulo no século XIX ${ }^{1}$
}

Food and urban transformations in 19th century São Paulo

\section{João Luiz Maximo da Silva \\ Doutor em História Social pela \\ Universidade de São Paulo \\ (FFLCH-USP/São Paulo-Brasil) e professor do Centro Universitário Senac-SP \\ e-mail: joao.Imsilva@sp.senac.br}

\section{Resumo}

Este artigo procura identificar algumas transformações nos espaços urbano e doméstico em São Paulo no final do século XIX, associada com o consumo de alimento nas casas e nas ruas. $A$ introdução de tecnologias como 0 fogão a gás e a trajetória dos cafés, restaurantes e novos cardápios, foram delineadas juntamente com a transformação da cidade, principalmente a questão sanitária, associada ao desejo das elites de modernização.

\section{Abstract}

This article intends to assess some urban and domestic space transformations in late $19^{\text {th }}$ century São Paulo, associated with the home and street consumption of food. The introduction of technologies like gas stove and the trajectory of coffee-houses, restaurants and renewed menus are outlined together with the urban transformation in the city, mainly the sanitary question associated with elite's desire of modernization.

Palavras-chave

cozinha, alimentação, São Paulo (século XIX), equipamento doméstico

Keywords

kitchen, food, São Paulo (19 ${ }^{\text {th }}$ century), domestic appliance
1

Este artigo trata de alguns temas desenvolvidos em minha tese de doutorado: SILVA, João Luiz Maximo da. Alimentação de rua na cidade de São Paulo (1828-1900). 2008. Tese (Doutorado em História). Faculdade de Filosofia, Letras e Ciências Humanas, Universidade de São Paulo, São Paulo, 1995. Agradeço as sugestões dos pareceristas que enriqueceram o texto final. 
2

MENESES, Ulpiano T. Bezerra de; CARNEIRO, Henrique. A história da alimentação: balizas historiográficas. In: Anais do Museu Paulista, v. 5. São Paulo: Nova Série, jan./dez. 1997. p. 9-91.

3

A região era conhecida como Triângulo porque abrangia as ruas Direita, São Bento e XV de Novembro, que formariam os vértices da figura de um triângulo que constituia o núcleo central da cidade. PRADO JR., Caio. A cidade de São Paulo. Geografia e história. São Paulo: Editora Brasiliense, 1983
Quando falamos em alimentação, abre-se uma enorme gama de possibilidades dentro de um campo que começa a se desenvolver na historiografia brasileira. Bastante explorada em áreas como a Antropologia ou Sociologia, no campo da História esse tema ainda engatinha. 0 objeto desse tipo de abordagem implica vários focos. Como apontam Ulpiano T. Bezerra de Meneses e Henrique Carneiro em relação ao campo da história da alimentação: "Há, pode-se ver, grande oscilação de sentido e centros de gravitação. Estas fronteiras estão longe de poderem ser claramente demarcadas e não é evidente que devam sê-lo."2 A interdisciplinaridade parece, assim, ser indispensável nos estudos sobre alimentação, principalmente em áreas do conhecimento que se preocuparam mais com o tema, como é o caso da Antropologia. No campo da História, apesar de ainda restritos, os estudos sobre alimentação vêm crescendo nos últimos anos.

No caso do presente texto, nossa intenção é esboçar algumas possibilidades e apontar questões potencialmente ricas para o estudo da sociedade paulistana no período em questão. Nossa atenção não se prende aos alimentos em si, mas às formas de preparação e consumo, que caracterizam novos espaços de articulação na cidade. 0 que pretendemos nesse texto é enfocar os novos espaços de abastecimento e consumo de alimentos e as modificações em seu preparo com a introdução de novos equipamentos domésticos e também o impacto das transformações urbanas no espaço da rua e do abastecimento e consumo aí realizados.

No bojo das transformações em curso na cidade de São Paulo no final do século XIX, as formas de alimentação da população também foram modificadas, seja na casa seja na rua. No processo de urbanização, as autoridades e as elites procuraram dar nova forma à cidade, modificando principalmente a área central de São Paulo, a região do Triângulo, ${ }^{3}$ transformada em área de comércio elegante. Qualquer hábito identificado com o passado colonial era estigmatizado e combatido pelas autoridades. A nova legislação urbana (Código de Posturas e Código Sanitário) foi um importante instrumento nesse sentido. Nesse artigo, pretendemos discutir alguns pontos iniciais dessa questão, procurando relacionar as grandes transformações urbanas com uma atividade elementar, a alimentação. Aqui, trataremos das modificações no cardápio e nas formas de sociabilidade representada pelo hábito de comer na rua, além do impacto das novas tecnologias domésticas no preparo da alimentação.

Podemos dizer que a cidade de São Paulo, com traços marcadamente coloniais, foi crescendo e hábitos como a venda de alimento nas ruas, e mesmo um tipo de cardápio tradicional, foram sendo combatidos e substituídos por formas consideradas como "modernas". Esse é o período do surgimento do fogão a gás em algumas casas e comércio paulistanos, e também do surgimento dos mercados, cafés, confeitarias e restaurantes. A rua e o espaço doméstico sofreram grandes transformações, e a alimentação pode ser uma excelente plataforma para entendermos esse processo e suas articulações.

\section{Alimentação nas ruas}

A alimentação nas ruas foi afetada pelas transformações urbanas, tendo como ponto de apoio a higienização, mas foi a necessidade de desobstruir a cidade e embelezá-la que provocou as primeiras transformações no abastecimento, consumo e venda de alimentos nos logradouros públicos de São Paulo. Desde o século XVIII, a cidade conhecia formas de se alimentar nas ruas que se caracterizavam não apenas pela presença de quitandeiras, 
BRUNO, Ernani Silva. Histórias e tradições da cidade de São Paulo, 3 v. São Paulo: Editora Hucitec, 1991. p. 293

DIAS, Maria Odila Silva. Quotidiano e poder em São Paulo no século XIX. São Paulo: Editora Brasiliense, 1995, p. 77

6

A influência africana era percebida no tipo de alimento vendido nas ruas da cidade: carurus, vatapás, acaçá, acarajé, bobó, etc. 0 uso do óleo de dendê, coco, e a associação às religiões de origem africana nas comidas de rua denotam essa grande influência. Para Câmara Cascudo, uma concentração negra mais homogênea na cidade de Salvador teria possibilitado o desenvolvimento de uma culinária mais ligada às tradições africanas. Em torno dos candomblés, do culto jejê-nagô, a cozinha teria mantido elementos primários de coesão e sobrevivência dessas comunidades. As comidas associadas aos cultos de origem africana teriam permanecido nas ruas de Salvador. CASCUDO, Luis da Câmara. História da alimentação no Brasil. São Paulo: Global, 2004. p. 824-825.

Analisando a sociedade paulista dos primeiros séculos, Sérgio Buarque de Holanda dedicou um capitulo ao papel do milho no período colonial e outro às 'iguarias de bugre.' Intitulado "Civilização do milho", o primeiro trata da adoção do milho e sua farinha na dieta dos paulistas e seu papel em uma sociedade em constante movimento pelo sertão. No segundo, o autor trata de outro componente importante da dieta paulista, 0 uso de alimentos silvestres como içá, bicho de taquara e assemelhados. HOLANDA, Sérgio Buarque de. Caminhos e fronteiras, 3.ed. São Paulo: Companhia das Letras, 1994.

8

Muitas das informações relativas à alimentação nas ruas da cidade de São Paulo nesse período devemos aos relatos de viajantes e moradores. Devemos considerar que se trata de um público letrado, parte da elite que estava de passagem pela cidade ou nela estava a estudo, como é o caso de vários estudantes da Faculdade de Direito do Largo são Francisco. Para Ana Brefe, o que orienta os relatos memorialistas é a "preocupação em dar conta das múltiplas mudanças pelas qual a cidade passava. Pode-se dizer que esses relatos, ao investirem intensamente na caracterização e descrição da São Paulo da virada do século $X X$, inventam e reinventam continuamente o espaço urbano, dotando-o de símbolos, marcos e identidades". Procuramos considerar essa caracteristica desse tipo de fonte para tratar do tema. BREFE, Ana Cláudia Fonseca. A cidade inventada. A paulicéia construida nos relatos memorialistas (1870-1920). 1993. Dissertação (Mestrado em História). Universidade de Campinas, Campinas, 1993.

9

SAINT-HILAIRE, August. Viagem à província de São Paulo. São Paulo: Edusp, 1976. p. 132.

10

MARTINS, Antonio Egydio. São Paulo antigo, 1554-1910. Coleção São Paulo, 4. São Paulo: Paz e Terra, 2003. p. 285. mas de um pequeno comércio destinado ao abastecimento da cidade. Para Ernani Bruno ${ }_{1}^{4}$ o comércio em torno da distribuição de alimentos teria se desenvolvido desde os primórdios da cidade, mas apenas no final do século XVIII e início do século XIX teria consubstanciado traços urbanos, no que a historiadora Maria Odila Dias chamou de "incipiente urbanização", diferenciando do processo de urbanização do final do século XIX em São Paulo.

0 comércio de alimentos nas ruas de São Paulo no século XIX era intenso e se caracterizava pela presença das quitandeiras em vários pontos da cidade, obviamente os mais movimentados. Os vendedores se espalhavam por vários pontos do núcleo central da cidade: rua das Casinhas (atual rua do Tesouro), rua da Quitanda, largo da Misericórdia, largo São Bento e até mesmo no Pátio do Colégio. As quitandeiras representaram boa parte desse comércio de rua na São Paulo do século XIX. A expressão "quitandeira" era imprecisa, englobando senhoras, escravas e negras forras, em um comércio miúdo, que muitas vezes escapava da fiscalização e servia a uma população itinerante em uma cidade ainda colonial. ${ }^{5}$

Nessa conjuntura, marcada pelo escravismo e uma cultura voltada para a exportação, o comércio de alimentos se apresentava de forma desorganizada, mas com uma crescente importância na cidade de São Paulo. Os viajantes que passavam pela cidade entre os séculos XVIII e XIX se impressionavam com o intenso (e desorganizado) comércio nas ruas. Além do serviço de abastecimento aos moradores, havia um grande consumo de alimento na própria rua. Ao contrário de Salvador, onde a grande presença de escravas e libertas de origem africana influenciou fortemente o cardápio do que era servido nas ruas, em São Paulo a predominância do cardápio indígena foi marcante. ${ }^{6}$ Em São Paulo, o cardápio da rua era dominado por petiscos baseados nas "iguarias de bugre" (içás torradas, pinhão cozido, amendoim, etc.) e na farinha de milho (bolos, pastéis, cuscuz, etc.).?

As casinhas eram o ponto principal de venda de mantimentos trazidas pelos tropeiros, e grande responsável pelo abastecimento dos moradores, talvez o primeiro mercado da cidade, caracterizado por pequenas portas localizadas na chamada rua das Casinhas. Os relatos de viajantes e memorialistas são bastante úteis para que possamos identificar algumas dessas transformações em relação à alimentação, principalmente na rua. ${ }^{8}$ Esse é o caso de August de Saint-Hilaire, que descreve a rua das Casinhas (principal ponto de distribuição de alimentos da cidade), como um local com pequenas casas sujas, enfumaçadas e sem limpeza e ordem. A frequência também não era bem vista: negros, camponeses, tropeiros, além da presença de prostitutas durante a noite. ${ }^{9}$

Mas o principal ponto de consumo de alimentos era o largo da Misericórdia. Ali as quitandeiras estacionavam durante a noite para vender doces, biscoitos, cuscuz de bagre, empadas, entre uma grande variedade de alimentos expostos em tabuleiros..$^{10}$ Apesar das reclamações constantes contra a sujeira, a principal preocupação das autoridades era com a circulação. Já em 1829, propunha-se a criação de um espaço mais adequado para essas atividades que, no entanto, se estenderam até o final do século XIX espalhadas por vários pontos. Havia constantes conflitos das quitandeiras com as autoridades municipais que tentavam disciplinar esse tipo de comércio durante as primeiras décadas do século XIX. 0 crescimento e a necessidade de se ordenar e limpar o espaço urbano (mais precisamente a área do Triângulo) levou a duas atitudes das autoridades: dificultar e segregar cada vez mais o trabalho das quitandeiras e a construção dos primeiros mercados. 
CAMARGO, Daisy de. Alegrias engarrafadas. Os alcoóis e a embriaguez na cidade de São Paulo no final do século XIX e começo do século XX. São Paulo, Editora Unesp, 2013. p. 105

12

DAECTO, Marisa Midori. Comércio e vida urbana na cidade de São Paulo (1889-1930). São Paulo: SENAC, 2002, p. 167-168.

13

MARTINS, Antonio Egydio. Op. Cit. p. 152-153.

14

BRUNO, Ernani da Silva. Op. Cit. p. 1132

AMERICANO, Jorge. São Paulo naquele tempo: 1895-1915. São Paulo: Melhoramentos, 1962.

16

A esse respeito, ver MANZONI, Francis. Campos e cidades na capital paulista: São Paulo no final do século XIX e nas primeiras décadas do século XX. História \&t Perspectivas, Uberlândia, n. 36-37. p. 81-107, jan./dez. 2007.
Embelezamento e higiene

No último quartel do século XIX, o crescimento da cidade exigia uma transformação da área central que se transfiguraria em um espaço elegante voltado para o comércio da elite. As ruas Direita e 15 de Novembro são os grandes exemplos desse novo perfil. As ações públicas se espalhavam pelos principais pontos da cidade, buscando uma redefinição dos espaços tendo em vista a ideia de especialização das funções urbanas. Analisando o comércio de bebidas alcoólicas na cidade de São Paulo nesse período, Daisy Camargo aponta a importância da fiscalização a cargo dos engenheiros. ${ }^{10} 0$ discurso oficial passa a ser escudado pela suposta neutralidade técnica que deveria intervir nos espaços urbanos e também doméstico. Assim, as atividades ligadas à alimentação também seriam modificadas. As quitandeiras e as áreas de abastecimento como as Casinhas começam a ser substituídas pelos mercados e o surgimento dos cafés e restaurantes. Um processo similar ao que ocorre em relação a alimentação nas casas. Qualquer conotação de atraso ou parentesco com a antiga cidade colonial passa a ser combatida. Mudavam os espaços de sociabilidade (em especial aqueles ligados à alimentação) e também o cardápio, tudo em prol de uma cidade ordenada e limpa.

Uma das questões mais graves no tocante à alimentação era 0 comércio de carne. Os açougues, que cresceram muito na segunda metade do século XIX, foram afastados das ruas centrais a partir de 1890 . Se os mercados ficaram na margem da área do triângulo, o perímetro dos açougues foi estabelecido em uma área mais distante. ${ }^{12} 0$ matadouro, que ficava no curral do Concelho na estrada de Santo Amaro em 1852, foi estabelecido na rua Humaitá, mas as águas do tanque do Matadouro corriam no rio Anhangabaú, chegando até a região central, constituindo-se em um grave problema sanitário. Esse problema só foi sanado com a construção do Matadouro da Vila Mariana, que passou a utilizar o trem no transporte de carne, remodelando completamente esse tipo de comércio que, assim, ficava afastado na região central da cidade. ${ }^{13}$

0 comércio de abastecimento da rua das Casinhas também começou a declinar com a construção dos primeiros mercados da cidade. Além do mercado do Tamanduateí, aberto em 1867, a cidade passou a contar com o mercado de verduras da avenida São João (1890), um barracão no Largo São Paulo que servia como depósito de carne verde (1899) e, a partir de 1914, com as feiras livres..$^{14}$ Apesar disso, alguns desses mercados ainda eram considerados sujos, como era o caso do mercado de verduras de São João. 0 marco desse período foi a construção do chamado "Mercado Grande" na rua 25 de Março, próximo ao rio Tamanduateí. Construído em pavilhões de alvenaria, passou a centralizar a distribuição de alimentos que vinham das chácaras dos subúrbios de São Paulo. ${ }^{15}$

Além dos mercados, situados nos limites da cidade, havia uma grande quantidade de chácaras nos arredores, com hortas, pomares e diversos tipos de plantação. Essas chácaras faziam parte do comércio alimentício da cidade. 0 processo de transformação da área central também atingiu essas chácaras. As grandes áreas "vazias" no entorno do núcleo central, foram alvo da especulação imobiliária e ações urbanísticas. ${ }^{16} \mathrm{~A}$ produção e o comércio de alimentos era um dos principais alvos das autoridades, no sentido de disciplinamento e da reorganização do espaço urbano.

0 comércio de rua também começava a se modificar e o grande alvo das autoridades eram as velhas quitandeiras. Além da questão do embelezamento e melhoria da circulação na área do Triângulo, essa atividade era 
17

Código de Posturas do município de São Paulo, 06/out./1886. p. 29

18

DIAS, Maria Odila Silva. Op. Cit. p. 243-244.

19

ROLNIK, Raquel. A cidade e a lei: legislação, política urbana e territórios na cidade de São Paulo. São Paulo: Fapesp/Studio Nobel, 1997. p. 66.

CAMARGO, Daisy. Alegrias engarrafadas, Op. Cit. p. 115.

vigiada pelas novas normas higiênicas e sanitárias, mas foram toleradas até 0 final do século XIX. 0 Código de Posturas de 1886 determinava a venda de alimentos no mercado, mas em seguida emendava que a disposição do artigo não impedia que as quitandeiras mercassem pelas ruas. ${ }^{17}$ Segundo Maria Odila Dias, o que expulsou as quitandeiras negras das ruas do centro foi a urbanização e a consequente valorização dessa área, sendo elas alijadas de suas residências e de seu ganha-pão. 0 comércio de rua ainda persistia, mas verificava-se uma mudança nos vendedores e no cardápio. Em 1876 as quitandeiras reclamaram às autoridades da expulsão das ruas onde sempre tinham vendido. ${ }^{18}$ Para a limpeza dessa área da cidade, era necessária a expulsão das populações pobres, majoritariamente negras, desmontando seu território, encravado na região central.

\footnotetext{
Desmontá-lo apagando os traços afro-brasileiros da cidade era fundamental para intensificar o poder das aparências europeias e conferir uma imagem "metropolitana" à cidade e à República nascente. (...) 0 ataque era simultaneamente real e imaginário; como em toda a operação urbanistica, tratava-se de associar um conjunto de intervenções físicas a uma rede de significados culturais e políticos. (...) Isso se deu por meio de reformas urbanas que deslocaram territórios negros e bloquearam seus circuitos, bem como através de uma ampla desqualificação e estigmatização desse território, em nome da luta contra a promiscuidade." ${ }^{19}$
}

0 desmonte do Centro Velho começou com a tentativa de retirar as quitandeiras do Largo do Palácio, em 1877. 0 que estava em questão era a espacialização funcional da região, com a transferência das residências de elite inicialmente para a região dos Campos Elíseos e a expulsão da população pobre para os cortiços e para os nascentes bairros operários. 0 marco desse movimento foi a desapropriação e demolição da Igreja do Rosário e das casas contíguas, onde se concentravam os negros para a venda de suas quitandas. Esta área deu origem à Praça Antonio Prado, que se tornaria um dos principais pontos elegantes da cidade no final do século XIX. Essas transformações estavam sob a égide do Código de Posturas de 1886 que procurava delimitar o espaço da rua como espaço de circulação e do Código Sanitário de 1894, que procuravam "limpar" a cidade e, posteriormente, atacar os cortiços. Esse processo atingia além das moradias das pessoas mais pobres, também o comércio dessa gente que precisava ser retirado da área central, em prol de novas formas de sociabilidade por intermédio da comida e da bebida. A historiadora Daisy Camargo identifica essas mesmas preocupações no comércio de bebidas, que se espalhavam por todos os setores da vida urbana, configurando "estratégias de disciplinamento da população por meio do conforto proporcionado pela infraestrutura", como é o caso do gás e da eletricidade aqui discutidos. ${ }^{20}$

Podemos verificar esse processo em todas as esferas da vida urbana. Se os mercados ajudaram a organizar a atividade de abastecimento na cidade, agora fora da área central, foi o surgimento dos cafés, restaurantes e confeitarias que daria um ar moderno e cosmopolita que a cidade de São Paulo e suas elites buscavam. As formas de se alimentar nas ruas vindas desde os séculos anteriores continuavam a existir, mas, no final do século XIX, o que chamava a atenção de viajantes e memorialistas era o grande número de cafés, restaurantes e confeitarias. Uma referência constante, anterior a essas mudanças, é o café de Maria Punga. Segundo Afonso Schmidt, teria existido entre 1850 e 1860 e ficava na Rua da Imperatriz (atual 15 de novembro). A comparação do autor é com os cafés do final do século XIX: 
SCHMIDT, Afonso. São Paulo de meus amores, Coleção São Paulo 1. São Paulo: Paz e Terra, 2003. p. 113.

DINIZ, Firmo de Albuquerque (Junius). Notas de viagem. São Paulo: Governo do Estado, 1978. p. 81
Não tinha mesas redondas, cadeiras de palhinha e balcão de mármore. Tampouco se parecia com os atuais, onde a gente chega, compra um cupão na caixa, acerca-se do balcão de zinco e ingere ali mesmo o aguado líquido, de pé, sem dirigir a palavra ao vizinho (...) Nessa sala havia mesa grande, encardida, cercada de mochos que faziam as vezes de cadeiras. Os fregueses eram escassos, pois toda gente morava ali mesmo na Rua da Tabatinguera, na Rua do Príncipe ou no Pátio de São Gonçalo. Só mesmo estudante, meirinho, boiadeiro ou gente de fora entrava no café da Maria Punga. ${ }^{21}$

Ao contrário, os cafés da São Paulo da virada do século eram lugares limpos e organizados, um local onde a elite podia passear e tomar seu café, apesar da pressa que passava a caracterizar a vida urbana. A região do Triângulo, antes frequentada por boiadeiros, negros e pobres da região, tornou-se a região do comércio elegante da cidade. Os novos fregueses eram funcionários de bancos, comércio e escritórios, além dos estudantes da faculdade de direito, que tinham por hábito frequentar a região desde a fundação da faculdade. 0 que muda nos locais de alimentação da cidade é a forma de sociabilidade, que passa a estar afinada com a urbanização da antiga vila.

Apesar disso, o antigo cardápio oferecido por Maria Punga parecia agradar aos seus fregueses. Um cardápio identificado com o passado da cidade, as chamadas "iguarias de bugre" preparadas e vendidas por escravos e libertos. Ao contrário dos cafés que fizeram a fama da urbe, inspirados em seus congêneres europeus, esse estabelecimento era dirigido por Maria Punga, assim descrita: "Era preta e gorda. Usava toalha na cabeça, argola de ouro nas orelhas e, à guisa de enfeite, trazia sempre no colo um raminho de arruda e figa de guiné contra mau-olhado..." 0 café feito por Maria Punga era elogiado por Afonso Schimidt, mas o grande atrativo eram as quitandas que o acompanhavam, bolos de fubá, broinhas de polvilho e bolinhos de tapioca. Esses alimentos continuaram a ser vendidos nas ruas da cidade, mas foram lentamente recuando, dando lugar aos novos estabelecimentos comerciais e novos cardápios.

Sobre as mudanças na cidade de São Paulo no final do século XIX, podemos recorrer a Firmo de Albuquerque Diniz, alcunhado de Junius, que após estudar na faculdade do Largo São Francisco, viveu na cidade entre 1857 e 1860 . Retornando somente em 1882, ficou admirado com as transformações urbanas. Seu espanto foi com o surgimento de cafés, restaurantes e confeitarias. Comparando seu passeio em $1882 \mathrm{com}$ a cidade em que viveu em 1860, que considerava silenciosa e sem lugares para comer (provavelmente não era um frequentador do café da Maria Punga, como Schmidt), Junius fala sobre os novos estabelecimentos:

Seguindo o nosso caminho, fomos até o fim da rua Direita; dai descemos a rua do Rosário, e, a convite do jornalista, o Dr. Z... e eu entramos no Café Americano; onde tomamos assento a roda de uma das pequenas mesas: nos demoramos ali quase uma hora, conversando, e ouvindo algumas peças regularmente executadas por seis músicos italianos. ${ }^{22}$

Ao contrário do café da Maria Punga, onde tudo era improvisado, no Café Americano o ambiente era de encontro, conversas e música. Em seguida, nosso visitante fala sobre o cardápio que encontrou no mesmo Café Americano: "(...) o sujeito que apreciar o bife 'saignant' acompanhado do vinho do Porto, ou quiser cerveja, conhaque, ou qualquer outro líquido, que dê tom ao espírito, é só entrar no Café Americano, pedir, e gozar (...)."23 
Um bom bife mal passado talvez soasse mais delicado se pronunciado em francês e acompanhado de vinho do Porto. Um cardápio um pouco distante das quitandas de rua. Além do estabelecimento de uma nova sociabilidade urbana e mesmo o status relacionado ao hábito de se frequentar restaurantes e cafés, temos também de mencionar o papel desses espaços de alimentação no novo contexto urbano. Muitos dos frequentadores desses lugares trabalhavam na região central remodelada. Assim, o restaurante passa a ser necessário para pessoas que já não mais podiam fazer as refeições em casa.

De qualquer forma ainda persistia o comércio de ambulantes, inclusive de alimento nas ruas. A diminuição da presença das negras quitandeiras nas ruas foi acompanhada do crescimento de estrangeiros e de modalidades de comércio regulamentadas, como os quiosques. Apesar de regulamentados e sujeitos à concessão do poder público, assemelhavam-se mais aos antigos estabelecimentos, como o de Maria Punga do que aos elegantes cafés. Seu público era constituído por antigos escravos, vendedores de jornais, engraxates, vagabundos, vigaristas, etc. Mas o cardápio, chamava a atenção até da "gente boa" que passava, sardinhas fritas, bifes e lascas de fígado, tudo comido em pé no balcão. ${ }^{24}$

Quanto aos vendedores ambulantes, surgiam os italianos e o cardápio mudava. Saiam os pratos a base de milho, como o cuscuz, e chegavam a castanha assada, a pipoca e o amendoim. Essa mudança do comércio ambulante estava diretamente associada às transformações urbanas em curso:

\footnotetext{
0 comércio ambulante de comercialização incipiente foi aos poucos recuando das ruas do centro para os novos limites da pobreza urbana. Imigrantes portuguesas e italianas alugavam quartos e lojas de molhados na cidade ou chegavam ao centro com carroças carregadas de uvas, leite, manteiga, lenha e carvão; com sua presença, provocaram a remodelação do espaço urbano de sobrevivência e grande transformação no comércio de abastecimento. ${ }^{25}$
}

Por outro lado, alguns imigrantes eram responsáveis também pela introdução de novos cardápios. A Confeitaria Stadt Coblenz (fundada por alemães), situada à Rua Direita, oferecia em seu cardápio salada de batata, presunto de York, além de queijos suiços e chope. Os italianos começaram a introduzir fábricas de macarrão, além de um tipo de estabelecimento que iria marcar a cidade, as cantinas.

A alimentação nas ruas de São Paulo tomou novos ares, assim como se transformava lentamente o cardápio e as formas de preparo das casas paulistanas. Já ia longe o tempo em que os paulistas eram chamados de "comedores de içá", como no epigrama do estudante de direito Francisco José Pereira Guimarães: "Comendo içá, comendo cambuquira, vive a afamada gente paulistana, e os tais a quem chamam "caipira", que parecem não ser da raça humana." Nesse tempo, os estudantes encontravam uma pequena vila, sem os atrativos da nascente metrópole do final do século XIX. As cozinheiras não tinham que preparar mais que o trivial, feijão, arroz, carne de vaca ou porco e algum legume. Muito distante dos "nomes literários" ou "designações delicadas" dos pratos, aludida por Júlia Lopes de Almeida, ou do bife "saignant" do Café Americano, elogiado por Afonso Schmidt. Na São Paulo do final do século XIX, era possivel atender às expectativas aristocráticas das famílias abastadas: 
26

DINIZ, Firmo de Albuquerque. Op. Cit. p. 45.

27

DIAS, Maria Odila Silva. Op. Cit. p. 244.
28

COSTA, Jurandir Freire. Ordem médica e norma familiar. Biblioteca de Filosofia e História das Ciências, v. 5. Rio de Janeiro: Edições Graal, 1999 p. 28-29.
Pois hoje pode se oferecer um esplêndido banquete ao rei de Espanha, ao Czar da Rússia, ao Imperador Guilherme, ao rei Humberto, ou a qualquer outro possuidor de coroa, cetro ou trono, se nos obsequiarem com suas visitas; nada faltará: feita a encomenda ao meio-dia, às 7 horas da noite estará pronto o banquete, $\mathrm{e}$ luxuosamente servido com variedade de iguarias à Européia, de sobremesa, com profusão de vinhos de finas qualidades, Franceses, Portugueses, Espanhóis, Alemães, Italianos e Húngaros: os três hotéis de primeira ordem, as confeitarias, e várias outras casas oferecem todos os recursos para a realização de uma tal festa em condições de agradar as pessoas. ${ }^{26}$

Essa situação parece estar bem distante da imagem de pobreza e sujeira das antigas estalagens e pousos, que serviam cachaça e feijão com toucinho para tropeiros e gente pobre que circulava pelas ruas esburacadas da São Paulo colonial. Essa gente estava sendo expulsa para os novos limites da pobreza urbana. ${ }^{27}$ Bairros operários, como Brás, Mooca e Belenzinho cresciam junto com as fábricas e os imigrantes. Mas não foi apenas o espaço público das ruas que foi atingido fortemente pelas transformações urbanas: ainda que lentamente, os lares também sofreram esse impacto, passando a estarem articulados com o espaço urbano e suas transformações.

\section{Higiene e espaço doméstico}

Como discutimos anteriormente, a higiene surge como um dos grandes temas nas principais cidades brasileiras no final do século XIX. 0 grande alvo das autoridades foi a péssima condição sanitária das cidades. Epidemias, como a de febre amarela em 1893, levaram o Estado a medicalizar sua atuação. Seguindo uma tendência muito em voga na Europa, o Estado procurava disciplinar o espaço urbano visando, sobretudo, melhorar o escoamento de seu principal produto, o café. A necessidade de melhor circulação das mercadorias e de uma crescente elite tornou a salubridade a principal meta na melhoria das cidades. A medicina aliou-se ao novo sistema contra a antiga ordem colonial e, por intermédio da higiene incorporou a cidade e a população ao campo do saber médico. ${ }^{28}$

A higiene teve um papel decisivo nas transformações da cozinha, $\mathrm{e}$ de resto nas formas urbanas de alimentação nas grandes cidades brasileiras. Ao contrário dos Estados Unidos, onde a engenharia estava no primeiro plano, e da Europa, onde a arquitetura centralizava as discussões, no nosso caso, as autoridades médicas tiveram um papel de destaque, apoiadas pelas autoridades públicas. Num contexto de epidemias e necessidade de limpeza e organização da cidade, as antigas moradias e o espaço urbano despertaram a atenção das autoridades. Apesar de estarem na mira das autoridades, casa e rua representavam desafios diferentes no tocante ao controle $\mathrm{e}$ regulamentação da alimentação.

A presença de empregados domésticos (considerados como ignorantes e desprovidos de noções de higiene) associada à precariedade material na manipulação e preparo dos alimentos tornou a cozinha foco das medidas higiênicas. Nesse contexto, os saberes dos engenheiros e arquitetos estavam submetidos a essa lógica. Preocupações como aquelas relacionadas à organização do trabalho doméstico e diminuição das tarefas com a mecanização tinham pouca importância, seja devido à forte presença de trabalho pago, seja devido à hipertrofia do discurso médico.

A valorização do trabalho doméstico conduzido ou sob a supervisão da dona de casa, foi acompanhada da transformação de outros espaços da casa. Os manuais domésticos passaram a enfocar a importância da 
29

Durante o início do século XX, o grupo Light veiculou em jornais e revistas, anúncios de vários tipos de pequenos equipamentos domésticos elétricos, como torradeiras, aquecedores para comida, etc. Já a The San Paulo Gas Company, ligada ao grupo Light, centrou sua propaganda no fogão a gás. Cf. SILVA, João Luiz Máximo da. Cozinha Modelo. 0 impacto do gás e da eletricidade na casa paulistana (1870-1930). São Paulo: EDUSP, 2008.

30

CLESER, Vera A. O lar doméstico: conselhos para uma boa direcção da casa. Rio de Janeiro: Francisco Alves \& Cia., 1913.

31

Parecer do engenheiro Luiz Raphael Vieira de Souza apresentado pelos membros do Conselho Superior de Saúde Pública, na sessão de 8 de julho de 1886. Rio de Janeiro, Imprensa Nacional, 1886. In: ROLNIK, Raquel. Op. Cit. p. 41.

32

Habitações coletivas em São Paulo. Boletim da Sociedade de Medicina e Cirurgia de São Paulo, vol. IX, n. 4. junho 1926. p. 291-295. organização e limpeza. Mas esses valores eram tratados de forma diferente em relação ao que acontecia nos Estados Unidos. Lá, as preocupações estavam diretamente ligadas a uma demanda de tempo que envolvia a diminuição das tarefas. Antes mesmo do surgimento de equipamentos mecânicos, havia estudos sobre a organização do trabalho doméstico com o uso de superfícies de trabalho e diminuição dos esforços por intermédio do controle de movimentos na cozinha. Essa demanda estava associada a questões sociais, que exigiam por parte de engenheiros uma maior preocupação, já que o serviço doméstico estava a cargo da dona da casa. Este tipo de preocupação estava completamente fora da realidade brasileira, mesmo nos centros urbanos. Numa casa onde o trabalho estava a cargo de empregadas, o tempo não era uma questão critica.

Para um espaço até então esquecido e desprezado, a importância da cozinha aumentou muito, ao menos nas prescrições ancoradas na higiene. Além da comparação com os consultórios médicos, destaca-se o tratamento da cozinha como "laboratório", tanto nas propagandas de equipamentos quanto em manuais domésticos:29 "É absolutamente indispensável que volvamos toda a nossa atenção para o canto mais desprezado da casa, que vigiemos de perto o laboratório doméstico do qual sai o bem estar físico e moral de nossa família (...)."

Estava claro para as autoridades a necessidade de intervenção na cozinha. Em consonância com o discurso em voga, a organização do espaço não era apenas um caso de melhorar as condições físicas, mas, sobretudo, morais. Exemplo disso, podemos perceber neste parecer apresentado ao Conselho Superior de Saúde Pública em 1886: "(...) o melhoramento das casas dos operários tem um fim não só material, mas também político e moral. (...) Eis porque uma habitação de espaço agradável, bem arejada e iluminada, asseada e dotada de distribuição relativamente confortável, influi sobre a moralidade e bem estar da familia." ${ }^{31}$

Este tipo de descrição prosseguiu nas primeiras décadas do século $X X$, ressaltando a sujeira e precariedade da cozinha. A limpeza e organização das habitações dos trabalhadores eram consideradas essenciais para a moral. Quarenta anos depois, em 1926, o médico Francisco Figueira de Mello defendia a mesma teoria. Falando sobre a necessidade de habitações higiênicas, o médico enumera as vantagens:

\footnotetext{
A realização dessa empresa altamente patriótica trará consequentemente para a saúde pública o decréscimo dos casos de tuberculose, de moléstias infectocontagiosas, bem como a diminuição da mortalidade infantil. 0 alcoolismo, o roubo, os delitos, toda a série de fraquezas e misérias que a vida promíscua e sórdida gera, sofreriam um golpe de morte, fraquezas e misérias que pululam nesse ambiente malsão como pululam os germes de todas as infecções como numa fatídica simbiose para o arrasamento do físico e depravação do moral. ${ }^{32}$
}

As condições materiais estavam diretamente relacionadas aos maus hábitos identificados na casa, especialmente na cozinha, em contraposição ao revestimento de uma importância inédita reforçada pelos discursos higienistas. A necessidade de modificações era mais urgente ainda nas habitações operárias, onde a cozinha e as condições de preparo dos alimentos eram mais preocupantes.

0 discurso médico invadia todas as áreas influenciando os discursos de engenheiros, arquitetos e autoridades públicas, que seguiam a reboque da necessidade de se "domesticar" a família e a casa por intermédio da 
33

0 gás para uso doméstico (fogões) começou a ser fornecido em São Paulo em 1900 pela The San Paulo Gas Company, de origem inglesa. Essa empresa foi adquirida em 1912 pelo grupo Light que passou a controlar o fornecimento de gás e eletricidade em São Paulo e no Rio de Janeiro. A esse respeito ver SILVA, João Luiz Máximo da. Op. Cit. SOUZA, Edgard de. História da Light: primeiros 50 anos. São Paulo: Eletropaulo, 1989.

34

ALMEIDA, Júlia Lopes de. O livro das noivas. Rio de Janeiro: Francisco Alves \& Cia., 1905. p. 95-96.

35

0 esquema da panela de pressão foi desenvolvido pelo físico francês Denis Papin em 1861. GIEDION, Siegfried. Mechanization takes command: a contribution to anonymous history. New York: W. W. Norton, 1948. ordenação e limpeza, adotando uma rotina doméstica identificada com esse discurso. Uma das formas foi o aparelhamento da cozinha, não apenas em suas condições físicas (ladrilho, paredes impermeabilizadas, etc....), mas principalmente no preparo dos alimentos. 0 fornecimento de água, gás e eletricidade seriam capazes de transformar completamente esse processo, adequando a cozinha e suas práticas às necessidades estabelecidas pelas autoridades, e o fogão seria o principal equipamento doméstico.

\section{Alimentação no espaço doméstico}

Se o discurso higiênico atendia a uma demanda de limpeza e desobstrução da cidade, a exploração do gás e da eletricidade aproveitou-se desse discurso para fomentar e expandir o consumo de equipamentos domésticos. Como a cozinha parecia ser 0 alvo principal das preocupações das autoridades, 0 grupo Light, ${ }^{33}$ através da The San Paulo Gas Company centrou seus esforços na promoção do uso doméstico dos novos combustiveis, elegendo o fogão a gás como seu principal produto. A tecnologia oferecida pelas empresas estrangeiras prometia a adequação desejada da nova cozinha à higiene $\mathrm{e}_{\mathrm{r}}$ ao mesmo tempo, procurava vencer as defasagens e os antigos hábitos indesejáveis. Mas esse processo ignorou as condições históricas e culturais, impondo-se de forma a eliminar e substituir as antigas práticas. Nesse processo, as empregadas domésticas foram relegadas, em prol da dona de casa. 0 mesmo discurso médico, adotado por engenheiros, arquitetos e autoridades públicas, aparece no discurso publicitário, associando o fogão a gás com a higiene.

A alimentação estava em primeiro plano e inter-relacionada com outras questões, principalmente a higiene, e parecia adquirir, nesse contexto, um papel decisivo. Houve mudanças no preparo dos alimentos, que passaria a ser feito de forma limpa e higiênica, como ressaltavam as propagandas. Também o cardápio mudou, tendo em vista o surgimento de alimentos beneficiados oferecidos nos centros urbanos. Mas o principal para a boa dona de casa era o cuidado com a escolha da alimentação e a forma de preparo. Júlia Lopes de Almeida em seu manual para as noivas ressalta a importância de novas habilidades que as donas de casa deveriam ter no preparo das refeições:

Aí está uma coisa, para a qual, na minha opinião, deveria haver uma escola, onde se aprendesse a cozinhar com limpeza (...) Com o curso da escola, o cozinheiro saberia discernir com critério as qualidades e quantidades; teria noções de química, que o habilitassem a substituir por outro o pesadissimo, o brutal alimento com que se enche e amortece a população brasileira: o feijão, a carne seca, o cozido dariam lugar a coisas mais saudáveis... ${ }^{34}$

A cozinha deveria perder qualquer conotação ligada à experiência das cozinheiras, em prol da higiene e do saber técnico proporcionado pelo fogão a gás (entre outros equipamentos) e sempre sob a responsabilidade da dona da casa. Assim, não apenas o preparo seria afetado, com noções de química e conhecimento de novas técnicas, mas também a escolha dos alimentos. 0 feijão estava fortemente identificado com as classes mais baixas, mas era um alimento muito difundido por toda a população. Seu preparo estava associado à antiga cozinha, já que era um prato de preparo longo, que dependia de cozimento lento em panelas de ferro no fogão a lenha. A cozinha com o fogão a gás (chama concentrada e preço maior) e panelas de alumínio, não era adequada a este tipo de alimento (o que pôde ser corrigido com o surgimento da panela de pressão). ${ }^{35}$ 
ALMEIDA, Júlia Lopes de. Op. Cit. p. 105-106.

GRAHAM, Sandra Lauderdale. Proteção e obediência: criadas e seus patrões no Rio de Janeiro, 1860-1910. São Paulo: Companhia das Letras, 1992.

0 folclorista Luis da Câmara Cascudo tratou desses temas em seus livros. Segundo o autor, ele teria compendiado várias superstições, ouvindo velhas cozinheiras. A esse respeito, ver: CASCUDO, Luis da Câmara. Op. Cit.

Tanto os cursos para cozinheiras como os manuais domésticos ressaltavam o surgimento de um novo cardápio adaptado aos novos gostos. Júlia Lopes de Almeida, em seu manual dirigido às mulheres, fala com ironia sobre a nova "arte culinária":

(...) Desde que o enfarruscador oficio de temperar panelas se enfeitou com o nome de arte culinária, temos uma certa obrigação de cortesia para com ele. $\mathrm{E}$ concordemos que é uma arte pródiga e fértil. Cada dia surge um pratinho novo, com mil composições extravagantes, que espantam as menagères pobres e deleitam os cozinheiros da raça! Dão-se nomes literários, designações delicadas, procuradas com esforço, para condizer com a raridade do acepipe. Os temperos banais, das velhas cozinhas burguesas, vão-se perdendo na sombra dos tempos. Falar em alhos, salsa, vinagre, cebola verde, hortelã ou coentro, arrepia a cabeluda epiderme dos mestres dos fogões atuais. Agora em todas as despensas devem brilhar rótulos estrangeiros de conservas assassinas, e alcaparras, trufas, manteiga dinamarquesa (o toucinho passou a ser ignominioso), vinho Madeira para adubo do filet, enfim tudo o que houver de mais apurado, cheiroso e ... caro!36

Os cozinheiros começam a substituir as antigas cozinheiras do trivial, assim como os produtos beneficiados e industrializados (muitos deles importados) substituiam antigos ingredientes e alimentos. Os novos fogões e utensílios domésticos permitiam a modernização da cozinha e de seu cardápio, revestindo antigas práticas com um verniz de civilização e modernidade. Novos nomes, equipamentos e ingredientes para uma atividade tradicionalmente desprestigiada. Claro que essa possibilidade estava restrita aos lares mais abastados, mas essa visão se espalharia pelo restante da sociedade.

A habilidade no preparo de pratos demorados como o feijão e a carne, entretanto, era uma qualidade apreciada nas empregadas com larga experiência nas cozinhas antigas. Sandra Graham, analisando o trabalho doméstico, ressalta a competência exigida das criadas na cozinha:

As criadas que cozinhavam demonstravam ampla competência não apenas nos pratos que preparavam mas também nos equipamentos que usavam. Visto que cozinhar requeria ou o fogão ou o forno, a perícia de uma cozinheira era julgada de acordo com seus conhecimentos de forno e fogão. (...) o êxito de uma cozinheira dependia de sua habilidade para graduar e controlar a temperatura do forno. Ela podia, simplesmente, pôr a mão no forno e contar: se conseguisse chegar só até três, o forno estava quente, ao passo que vinte significava quase frio. ${ }^{37}$

Esse tipo de habilidade teve sua importância diminuída com os novos equipamentos. 0 fogão a gás dispensava os truques desenvolvidos pelas cozinheiras. Mais ainda, exigia outro tipo de conhecimento que se opunha à sua experiência, considerando-a fruto de atraso, identificada com a antiga cozinha suja e anti-higiênica. 0 trabalho nos fogões a lenha e carvão exigia da criada, além de uma maior mobilização física e gasto de tempo no preparo das refeições, o desenvolvimento de técnicas próprias.

Muitas vezes, o trabalho era acompanhado de uma série de crenças e superstições. A cozinha com carvão e lenha dava ao fogo características próprias, que definiriam o sucesso no preparo dos alimentos. Assim, operações aparentemente simples, como acender o fogo, eram determinadas por certos procedimentos e crenças, além de simpatias para a comida não queimar ou manter o fogo equilibrado nas várias operações. Entre outras coisas, não deveria ser apagado o lume com água e nem revolver o braseiro com instrumento metálico. 0 fogo feito com papel queimado não manteria o gosto da comida. ${ }^{38}$ 
BOSI, Ecléa. Memória e sociedade: lembranças de velhos. São Paulo: Companhia das letras, 1994, p. 371. A autora recolheu uma série de depoimentos e analisou em seu livro. 0 depoimento de D. Risoleta (nascida em 1900) é rico em descrições sobre o trabalho na cozinha, que ela exercia desde criança.

40

CLESER, Vera A. Op. Cit. p. 7.

41

ALMEIDA, Júlia Lopes de. 0p. Cit. p. 96-97
0 trabalho na cozinha também exigia da cozinheira o conhecimento dos tipos de panelas adequadas a cada tipo de alimento, sem a necessidade de receitas. Dona Risoleta relembra seu trabalho como empregada doméstica, principalmente nas atividades culinárias: "Sou cozinheira de forno e fogão. Se eu ia num lugar e comia bolo, chegava em casa e fazia igualzinho, sem receita, sem nada, só porque eu comi." ${ }^{39}$

A comida era preparada pela cozinheira de acordo com sua experiência e conhecimento empírico das quantidades corretas de ingredientes e temperos. Segundo D. Risoleta, ela acordava às quatro horas da manhã para acender o fogão a lenha e preparar o café da manhã. A variação de temperatura era conseguida com o uso das brasas, que mantinha quente comidas e bebidas (como o café) ao longo do dia. Ou ainda, para o preparo dos pratos, desde os mais rápidos até aqueles que exigiam cozimento prolongado. Tudo de acordo com o conhecimento da cozinheira sobre 0 equipamento, combustivel, utensílios domésticos e ingredientes.

A introdução de novos equipamentos e utensílios domésticos, como já foi dito, modificou sensivelmente esse processo, tirando a cozinheira do comando das tarefas de preparo dos alimentos em prol da dona da casa. A valorização das tarefas domésticas estava associada à necessidade de uma melhor organização doméstica segundo os preceitos higiênicos. Para esta mudança era absolutamente essencial que a dona de casa tivesse um papel destacado, valorizando o trabalho doméstico. Os manuais destinados às mulheres salientavam a importância desses pequenos trabalhos na organização cotidiana do lar: "Sim. Os trabalhos caseiros são insignificantes, fáceis, triviais, mas o conjunto destas insignificâncias é o conforto, a prosperidade, a doce e irresistivel atração do lar!"40

Além da elevação dos trabalhos domésticos, como forma de reorganizar o lar em torno da privacidade, havia também a necessidade de fixar o papel da mulher com destaque na execução e mais ainda no gerenciamento destas atividades. A definição de uma rotina para o estabelecimento da ordem na casa era um dos papéis destinados à dona de casa. 0 outro era o domínio sobre a nova tecnologia colocada à disposição da casa, o gás e a eletricidade. Para saber distribuir as atividades, de forma ordenada, era necessário que a dona de casa dominasse completamente a execução das tarefas. Isso a colocaria em posição superior às suas empregadas, como recomendava Júlia Lopes de Almeida em seu livro dirigido às futuras donas de casa, referindo-se à necessidade de um curso para noções de preparo de alimentos:

\footnotetext{
Assim, fica comprometida a nossa posição de ménagères, porque, ai de nós, pouco ou nada disso entendemos também! Somos na maior parte, umas inúteis donas de casa! É tempo de nos convencermos que a cozinha deve, muito especialmente, merecer nosso zelo, a nossa mais escrupulosa atenção. Aconselho a todas as que podem, ou têm a fortuna de serem bem servidas, o uso do fogão a gás como o mais limpo, o mais cômodo e o mais higiênico. ${ }^{41}$
}

As mulheres assumiriam assim, a posição de gerenciamento (ménagères), supervisionando o trabalho doméstico. Se o fogão a lenha exigia uma experiência que era adquirida ao longo do tempo, os novos equipamentos exigiam treinamento específico. As propagandas da companhia de gás ressaltavam essa necessidade de conhecimentos específicos na operação do fogão, mesmo que de uma forma implícita. 
Como vimos, trata-se de um momento interessante que aponta as intensas transformações pelas quais passava a cidade de São Paulo. Seguindo uma nova lógica, a introdução do gás e da eletricidade no espaço doméstico (bem como na rua) exigia adaptações inéditas, inclusive corporais. As mediações entre a cozinheira e os novos equipamentos eram maiores, e a existência de botões que controlavam a temperatura do forno e o tamanho da chama do gás, exigia aprendizagem. A experiência da cozinheira nas antigas formas de preparo já não eram mais suficientes e desejadas, e o domínio da nova tecnologia estaria a cargo da dona de casa. A dependência não era apenas em relação à instalação e manutenção do aparelho, mas estendia-se ao uso. 0 processo de aprendizagem era preocupação da empresa desde o início da exploração do uso doméstico do gás, não apenas por intermédio das orientações prestadas pela empresa, mas até mesmo pelas propagandas.

Essa reeducação consistia não apenas em aprender o manuseio de um novo equipamento, mas afastar as antigas formas identificadas com os fogões a lenha e com as empregadas. 0 novo equipamento exigia além de conhecimentos técnicos, uma nova experiência baseada em aprendizagem adquirida através de mediações externas e absorvidas com a rotina. Não era apenas o uso de um novo equipamento que se ensinava, mas novas formas de organizar a cozinha e as tarefas domésticas, privilegiando valores como ordem, disciplina e higiene.

Assim, o trabalho doméstico reformulado era valorizado na perspectiva da dona de casa e em detrimento das empregadas. À mulher caberia o gerenciamento da casa num sentido amplo. Não apenas no reordenamento do espaço e das atividades segundo novos preceitos, mas visto também como uma forma de gerenciamento econômico da casa. Não que a mulher devesse executar todas essas tarefas, mas conhecê-las para o melhor gerenciamento da casa. Isso envolvia não apenas o preparo dos alimentos (sob uma nova perspectiva), mas o equilibrio econômico e psicológico da casa.

0 saber baseado na experiência foi sendo lentamente substituído por formas mecânicas e mediatizadas representadas pelos fogões a gás. Os novos aparelhos domésticos representavam o saber técnico e científico que tomaria seu lugar na cozinha, sempre ligado à dona da casa, que dominaria os novos códigos. Antigas tradições no tocante ao preparo dos alimentos (e outras tarefas) recuaram perante a entrada no espaço doméstico de formas urbanas: industrialização dos alimentos, equipamentos mecanizados, padronização e ordenação das tarefas.

Segundo Michel de Certeau, que analisava as transformações no cotidiano, a cozinheira, que antes dirigia a operação da cozinha, viu-se despojada de seu saber fazer empírico em prol de um novo saber tecnológico que the escapava à compreensão. Esse saber se configurava por intermédio de novas mediações (do estado e das empresas privadas), mas passaria a estar sob os cuidados da dona de casa, que, se não tinha pleno domínio das técnicas, ao menos dominava os códigos de operação, sendo responsável pela educação da cozinheira nesse novo contexto. Se os resultados desse processo em regiões centrais como os Estados Unidos e Europa foram parecidos com o que ocorreu em nossos centros urbanos, os motivos foram diferentes. Falando sobre esse processo de substituição de antigas práticas e gestos no preparo dos alimentos, Michel de Certeau observa: "Os gestos antigos não foram relegados simplesmente por causa da entrada dos 
CERTEAU, Michel de; GIARD, Luce; MAYOL, Pierre. A invenção do cotidiano: morar, cozinhar, v. 2. Petrópolis: Vozes, 1996. p. 274. aparelhos eletrodomésticos na cozinha, mas por causa da transformação de uma cultura material da economia de subsistência que lhe é solidária." ${ }^{42}$

As mudanças nos equipamentos e utensílios domésticos faziam parte do processo de transformação do espaço doméstico e das atividades ali desenvolvidas, sob o paradigma da questão da higiene e intimidade da família. Se no caso brasileiro, o trabalho doméstico continuaria presente, seria necessário, entretanto, que esse estivesse sob uma rígida supervisão da dona de casa, sempre com o auxilio de novas formas de preparo dos alimentos. Aproveitando-se desse momento, e ao mesmo tempo reforçando-o, as empresas de energia colocaram o gás e a eletricidade à disposição das donas de casa.

Podemos considerar que há uma grande similaridade entre os processos de transformação ocorridos na casa e na rua no período que tratamos. As ações do poder pública, na maioria das vezes, estavam em consonância com as transformações urbanas empreendidas por empresas como o grupo Light. Trata-se de um momento decisivo, quando casa e rua passam a estar cada vez mais submetidas à lógica das transformações urbanas pelas quais passavam centros urbanos brasileiros como a cidade de São Paulo. Como procuramos demonstrar, as transformações relacionadas à alimentação estão profundamente imbricadas na urbanização paulistana, envolvendo articulações de amplas consequências, entre estado, capital (capital estrangeiro e seus interesses) e infraestrutura (novo vetor de produção do espaço urbano e doméstico).

Essas são apenas algumas questões iniciais que demonstram o imenso potencial do estudo da alimentação na história de São Paulo. 0 estudo das formas de alimentação em suas múltiplas modalidades, abastecimento, preparo, consumo, pode nos ajudar a analisar um importante período da história da cidade. Como já enfatizamos, a alimentação é uma importante plataforma para percebermos as articulações sociais presentes no desenvolvimento urbano de São Paulo. Além de aspectos relacionados à urbanização e a uma nova sociabilidade, a alimentação, especialmente na rua, pode indicar outras perspectivas que não foram abordadas nesse texto, como o desenvolvimento do gosto e da gastronomia associado aos novos espaços como cafés e restaurantes. Uma análise da indústria alimentar, em franco desenvolvimento no período, também pode ser extremamente enriquecedora para verificar novas modalidades de consumo urbanas. Nesse processo, a casa e a rua foram atingidas pelas transformações e 0 vertiginoso crescimento da cidade, sob a égide do sanitarismo. Não apenas as formas de sociabilidade, horários e estabelecimentos foram modificados, mas também o cardápio, estigmatizando formas antigas de se comer em casa e na rua. Mas as antigas formas continuaram a se insinuar, permanecendo nos interstícios da vida urbana e doméstica, resistindo, desaparecendo, transformando-se e convivendo com novas formas de alimentação, seja na casa, seja na rua. 